\author{
Available online at \\ http://journal.ugm.ac.id/jifnp \\ DOI: http://doi.org/10.22146/ifnp.33996
}

INDONESIAN FOOD AND NUTRITION PROGRESS

Indonesian Food and Nutrition Progress, 2018, Vol. 15, Issue 2

\title{
The Effect of a Drying Time and The Different of Storage Periods to The Quality and The Shelflife of Milkfish (Chanos chanos forsk.) Cooked by High-Pressure Cooker
}

Nurul Meutia Agustiari ${ }^{*}$ ), Ratna Ibrahim, Titi Surti

\author{
Department of Fisheries Products Technology, Faculty of Fisheries and Marine Sciences, \\ Universitas Diponegoro \\ Jl. Prof. H. soedarto, S.H-Tembalang, Semarang, Indonesia, 50275 \\ ${ }^{*}$ Corresponding author, email address: nurul.meutia@gmail.com
}

Received 16 March 2018; Accepted 29 November 2018; Published Online 30 November 2018

\begin{abstract}
Milkfish that have been seasoned with some spices then cooked by a high -cooker produced a fish product which has soft spines and bones. The product which has a local name bandeng presto has been popular in Indonesia due to the product is tasty and it is easier to be consumed directly after it is prepared as a dish. The storage life of bandeng presto is relatively short, which is due to deterioration process by microbes after processing. Consequently, this condition can retard the products distribution. The aims of the research are to understand is there any significant influence of differing the drying time ( 0 hours and 4 hours) of milkfish cooked by a highpressure cooker by using an electric oven $\left(50^{\circ} \mathrm{C}\right)$ and storage period at room temperature ( 5 days) and also to find out which treatment produce the best product quality. The results showed that the treatment of differing the drying period gave a highly significant influence $(P<0.01)$ on the sensory value and the moisture content but did not gave significant influence $(P>0.05)$ on the number of bacteria colonies. The length of storage period gave a highly significant influence $(P<0.01)$ on the sensory value between the products which were dried for 4 hours and without drying treatment but only the drying process for 4 hours gave a highly significant influence $(P<0.01)$ on the moisture content, the water activity and the number of bacteria colonies. The quality of the products that were dried for 4 hours were better and their storage life can reach up to 3 days compared to the products that were not dried.
\end{abstract}

Keywords: Milkfish, high pressure cooker, drying, oven, quality, storage life

\section{Introduction}

Milkfish is usually consumed in its fresh form because it is known to be savory, has a distinctive aroma and pure white in color appearance. However, it has many spines which makes it difficult to be consumed. In the past, the rural community processed it simply through traditional process called pemindangan. Pemindangan according to
Ibrahim (2003), is the process of boiling fish with salt and water in waterproof containers (e.g. pendil, paso, badeng) or fish arranged in a container (e.g. bamboo basket, naya, reyeng, besek) which then boiled with a concentrated salt solution in an impermeable container, under normal pressure, without any further preservation process. Generally, containers 
that used at boiling process are used as product packaging during distribution.

Pemindangan according to Pandit (2004); Alyani et al. (2016), is a technique on processing and preservation by boiling or steaming fish in a salty atmosphere for a certain period of time in a container and then the process of reducing water content to a certain extent.

As the technology and demand of more nutritional intake are advancing, processing milkfish with pressure cooker is created (Djarijah, 1995). The definition of pressure cooker according to Hornby (2000) is a pot that is made of strong metal with a tight cover and its use to cook food quickly with highly pressure steaming process. Some people have called pressure cooker with presto, which according to Wojowasito (1982) means fast. The presto term comes from the name of a pot or a high-pressure cooker (Saparinto et al., 2006).

The advantage of presto is that the fish meat and spine get softened, thus it calles softspiny fish. Raw materials for presto fish are usually milkfish (Sudarisman and Elvina, 1996). As the spines becomes soft, it is safe to be consumed and the nutritional value is not affected and easily presented (Djarijah, 1995).

In Central Java, the center of milkfish production located in Semarang. Through sales agents, these products can find in Jakarta, Bandung, Lampung and other areas. Presto milkfish both traditionally and modernly processed can only be stored for two days at room temperature because the water content is still contained relatively high (Sarnianto et al., 1984). Indonesian National Standard of presto milkfish (SNI 4106.1:2009) requires that maximal water content in presto milkfish is $60 \%$. It is necessary to develop the technique of processing milkfish presto to extend the shelf life so that the distribution of presto milkfish can be done to various regions, especially outside production centers (Astawan, 2003).

Supardi and Sukamto (1999), explainedthat once the food contacts with environment and the growth condition supports, microbes will be active. A method to control microbe's growth is by limiting water as microbes need water.

Although some presto milkfish producer have applied a drying treatment to reduce water content in order to prolong the shelf life of presto milkfish, but no publication has been discussed fully about the effect of drying treatment on the storage period of presto milkfish seen from organoleptic value, moisture content, bacterial colonies and water activity in the product.

Based on the above problem, this research tried to apply the difference of drying time ( 0 hours and 4 hours) at $50^{\circ} \mathrm{C}$ temperature with electric oven to presto milkfish which packed with folding carton and kept at room temperature for 5 days.

\section{Materials and Methods Material}

The raw materials used in this research were fresh milkfish (Chanos chanos Forsk.) purchased from fishing ponds Semarang. Seasonings used in the process of presto milkfish were garlic, coriander, salt, turmeric, lemongrass, lime leaves and bay leaf.

\section{Methods}

Preparation of Seasoning Solution

Garlic, coriander, salt and turmeric were weighed then crushed with a blender (without adding water). Waters were added for every 175 grams of spice then stirred with a blender to mix evenly. The weight ratio of spices to water is 1:0,1 (Sintowardani, 1984 in Hidayati, 2004). The seasoning solutions were filtered to avoid clumps. The weight of milkfish and spice composition were presented in Table 1. 
Table 1. The weight of milkfish and spice composition

\begin{tabular}{cccc}
\hline Weight of Fish (g) & Spice & $\begin{array}{c}\text { Weight of Spice } \\
\text { (g) }\end{array}$ & $\begin{array}{c}\text { Percentage } \\
\text { (\%) }\end{array}$ \\
\hline 1000 & Garlic & 60 & 6.0 \\
& Coriander & 15 & 1.5 \\
& Salt & 75 & 7.5 \\
& Turmeric & 25 & 2.5 \\
& Lemongrass & 2 stem & - \\
& Bay leaf & 8 leaf & - \\
& Lime leaves & 5 leaf & - \\
\hline
\end{tabular}

Preparation of Milkfish Cooked by A High Pressure Cooker

Milkfish cooked by a high pressure cooker processing procedure refers to one of the presto milkfish producer in Semarang. Fresh milkfishes with weight sizes ranging from 200 - 250 grams and total length ranged between 25 - $26 \mathrm{~cm}$ were washed until clean and then made butterfly fillet and taken out the contents of his stomach (gills were not removed). Milkfishes were washed again with running water then all parts of the surface of milkfish smeared with a seasoning solution with a brush. Each seasoned milkfish were arranged in layers at the stainless steel container (if on the base layer fish head position is in one side then the above layer must be on the opposite side). Milkfishes were cooked for 1,5 hours. Cooking time was calculated after a hissing sound comes out from the pressure cooker and the ballast button lifted up. After cooking time is complete, wait 30 minutes until pressure in the cooker normal then opened. Milkfish cooked by a high-pressure cooker (Oxone OX-1070 Presto Pressure Cooker) were drained and cooled at room temperature.

\section{Preparation of Dried Milkfish Cooked by A High Pressure Cooker}

The drying process of presto milkfish used an electric oven refers to the method taken from Moedjiharto (2002). Samples of milkfish cooked by a high pressure cooker were taken as much as six pieces, then prepared on a sheet coated with aluminum foil to make it not too sticky. After that, sample were dried by an electric oven (Local Brand) at temperature $50^{\circ} \mathrm{C}$ for 0 hours and 4 hours. Everyone hour, each fish was flipped to avoid them burned and the dryness level was evenly. The sample was then cooled at room temperature and kept at room temperature for 5 days.

\section{Physicochemical Analyses}

Moisture Content

Analysis of moisture based on SNI 2354.2:2015 (National Standardization Council, 2015). Porcelain cups were weighed. Samples were minced with blender (Philips HR 2115) then inserted into the porcelain cup and weighed (Scaltec SDL 3). Porcelain cup with samples were dried in an oven at $105^{\circ} \mathrm{C}$ until it weighted constant then cooled in the desiccator for about 30 minutes and weighed. Weighing was repeated until the result is constant.

\section{Water Activity (Aw)}

Water activity were analyzed using Aw meter (Retronic). Samples were minced with blender (Philips HR 2115) inserted into a special plastic container. Samples were inserted into the detector then wait for 15 minutes until the value of samples recorded in screen. 


\section{Microbiological Analyses}

Standard plate count method based on SNI 2332.3:2015 (National Standardization Council, 2015) was used to analyze the growth of bacteria during storage. Samples as much as 20 gram inserted into petri dish then weighed (AND EK-2000i). The weighed sample was chopped until smooth by using scissors then added with $225 \mathrm{~mL}$ of sterile Butterfields Phosphate Buffered (BFP) solution (Merck 1048730250) and homogenized for one minute. Taken as much as $1 \mathrm{~mL}$ using a sterile pipette, then put into a reaction tube containing $9 \mathrm{~mL}$ of BFP solution. Serial dilutions were made and aliquots $(1 \mathrm{~mL})$ of each of each dilution were plated into petri dishes containing Plate Count Agar (PCA) (OXOID $\mathrm{CM}$ 0325). Plates were incubated (Memmert B40) for 48 hour at $350 \mathrm{oC}$. After incubation, colonies of bacteria were counted using colony counter and reported as colony forming units per $\mathrm{g}$ of sample (CFU/g).

\section{Sensory Evaluation}

Sensory evaluation based on SNI 4106.1:2009 (National Standardization Council, 2009). The test was performed with a trained panelist. The test method used in this standard was the scoring test with criterion one as the lowest score and nine for the highest score. The limit of rejection for presto milkfish was seven according to the standard of SNI 4106.1:2009.

\section{Statistical Analyses}

Results of physicochemical and microbiological analyses were subjected to ANOVA and Tukey tests. Results of sensory evaluations were subjected to Kruskal-Wallis tests. Statistical significance was expressed at the $99 \%$ significance level $(P<0,01)$.

\section{Results and Discussion}

\section{Physicochemical Analyses}

Moisture Content

Avery significant difference regarding the moisture value were observed in the treatment of drying time 0 hours and 4 hours and storage period 1,3 and 5 days at room temperature $\left(29^{\circ} \mathrm{C}-35^{\circ} \mathrm{C}\right)$ and a very significant difference between the moisture value of dried presto milkfish for 0 hours and 4 hours either on the 1st, 3rd day or 5th day storage $(P<0.01)$. The results moisture content of milkfish cooked by a high-pressure cooker enumeration shown in Table 2.

Differences in moisture content between the drying milkfish cooked by a highpressure cooker probably because there was a water evaporation process from product to the air by utilizing heat energy. The water evaporation process may occur presumably because there was a difference in the vapor pressure between the dried product and the air vapor pressure. Based on Adawyah (2007), explains that the drying process by means of water evaporation is done by reducing air relative humidity by passing the heat around the material, so that the water vapor pressure of the material is greater than the air vapor pressure of the surrounding. The pressure difference causes the movement of water vapor from material to air.

The heat also could reduce moisture content because of denaturation. At low temperatures $(<40 \quad \mathrm{C})$ the main structural changes will appear in the connective tissue due to denaturation of collagen. Water loss will, however, continue to increase with increasing temperatures due to denaturation of other proteins (Skipnes, et al., 2007).

The longer cooking time, the higher loss on the liquid of meat would be, until it reaches constant value. During the heating, the ability of protein to bind water decreased (Yusnaini et al., 2015). 
Table 2. Moisture content of milkfish cooked by a high-pressure cooker during storage at room temperature

\begin{tabular}{cccc}
\hline \multirow{2}{*}{ Drying Time (hour) } & \multicolumn{3}{c}{ Storage Period (day) } \\
\cline { 2 - 4 } & $\mathbf{1}$ & $\mathbf{3}$ & $\mathbf{5}$ \\
\hline 0 & $64.40 \pm 3.71_{\underline{\mathrm{a}}}$ & $65.71 \pm 1.23_{\underline{\mathrm{c}}}$ & $65.17 \pm 1.06_{\underline{\mathrm{e}}}$ \\
4 & $55.91 \pm 1.33_{\underline{\mathrm{b}}}$ & $60.62 \pm 1.46 \underline{\mathrm{d}}$ & $60.19 \pm 0.87 \underline{\mathrm{f}}$ \\
\hline
\end{tabular}

Values expressed are mean \pm standard deviation

Values with different subscript letters with the addition of underscores in the same Column are very significant differences $(P<0.01)$

Table 3. Water activity of milkfish cooked by a high-pressure cooker during storage at room temperature

\begin{tabular}{cccc}
\hline \multirow{2}{*}{ Drying Time (hour) } & \multicolumn{3}{c}{ Storage Period (day) } \\
\cline { 2 - 4 } & $\mathbf{1}$ & $\mathbf{3}$ & $\mathbf{5}$ \\
\hline 0 & 0.9905 & 0.9750 & $0.9920_{\underline{\mathrm{a}}}$ \\
4 & 0.9855 & 0.9840 & $0.9675_{\underline{\mathrm{b}}}$ \\
\hline
\end{tabular}

Values expressed are mean

Values with different subscript letters with the addition of underscores in the same column are very significant differences $(P<0.01)$

The difference in the relative humidity between the product and its environment will be a transfer of water. The moisture content of the drying presto milkfish for 4 hours at $3 r d$ day storage as well as the 5th day did not show any significant difference. This was probably because the relative humidity of the product and the relative humidity of the storage room had reached a balance then the moisture content of the stored product would be constant (Syarief et al., 1989).

\section{Water Activity (Aw)}

The water activity of milkfish cooked by a high-pressure cooker during storage of room temperature indicated that the drying treatment and storage period at room temperature $\left(29^{\circ}-35^{\circ} \mathrm{C}\right)$ was significantly different $(P<0.05)$ while for treatment of variation of drying time 0 hours and 4 hours during storage period 1,3 and 5 days were not significantly different $(P>0.05)$. The results water activity of milkfish cooked by a highpressure cooker enumeration shown in Table 3.

Water activity between drying milkfish cooked by a high-pressure cooker for 0 hours and 4 hours was very significant different at
5 th day storage $(P<0.01)$. This was mainly due to at the 5th day of storage, the number of bacterial colonies in the sample in 0 hours were high, in which the bacteria metabolism would be followed by water release, made the moisture content became higher. As a result, Aw value of dried-products for 0 hours was higher compared to those which dried for 4 hours.

According to Supardi and Sukamto (1999), microbial metabolism generally followed by water release and the results will be increase the value of water activity of food. At the storage day 1 and day 3 the water activity between the two products was not significantly different $(P>0.05)$. This was allegedly due to the water activity of both products adjusting to the state of the environment and achieving balance with the air humidity of the environment. Adnan (1982), explained that the activity of the food that stored in the room temperature will achieve balance with the environment air humidity.

Milkfish cooked by a high-pressure cooker dried for 0 hours or 4 hours had a relatively high value of water activity ranged from 0.966 to 1.000 so that the treatment of 
variation drying time could not decrease the value of the product water activity significantly.

For the sample with drying process for 0 hours on day 1 with day 3 , as well as same sample on day 3 and day 5 , gave a notable difference $(P<0.01)$. Meanwhile sample on day 1 and day 5 was not notably different $(P>0.05)$. The value of water activity of drying product for 4 hours on day 1 with day 5 and day 3 with day 5 was very significant different $(P<0.01)$ while on day 1 with day 3 was not significantly different $(P>0.05)$. During the storage at room temperature, the Aw of the product for 0 hours tended to fluctuate while those in for 4 hoursdrying process tended to decrease. This was allegedly due to the influence of the hydration process that caused the value of water activity to vary according to the circumstances of its environment. The statement is in accordance with the opinion of Fardiaz et al. (1992), that food both before and after processing is naturally hygroscopic, which means the food can absorb water from the air or otherwise release some of the water it contains into the air. Adnan (1982), explained that the activity of food water always varies according to the circumstances of its environment.

\section{Microbiological Analyses}

The variation of drying time ( 0 hours and 4 hours) and storage period ( 1,3 and 5 days) at room temperature gave a very significant difference to bacterial colonies $(P<0.01)$. There was a very significant difference between the number of bacteria colonies of drying presto milkfish for 0 hours with drying products for 4 hours on day $1(P<0.01)$, while on day 3 and day 5 the number of bacteria colonies of both products were not significantly different. The results of the bacterial colonies in the sample shown in Table 4. This difference was presumably because the drying process with an electric oven at $50^{\circ} \mathrm{C}$ could evaporate free water that contained in products where microorganisms could only grow and develop by utilizing free water, so that with the reduced moisture content of the product especially free water, would inhibit microorganisms to grow and develop. The statement is in accordance with the opinion of Adnan (1982), that free water can easily be lost in the evaporation or drying process. Kanoni (1991), explained that the free water that has evaporated through the drying process will lead to the development of microorganisms inhibited. In those conditions, metabolism and survival of microorganisms will not be achieved because the metabolic processes of microorganisms depend on the availability of water that can dissolve the nutrients necessary for the development of microorganisms.

The number of bacteria colonies in the sample both dried for 0 hours and 4 hours at room temperature storage day 1 was less than day 3 and 5 . Presumably due to the storage of the 1st day, the bacteria present in both products was because the contamination during cooking or after cooking in the lag phase. The lag phase is an early bacterial growth phase. In this phase, the bacteria are adapting the state of the environment. Winarno (1994), explained that microbes that contaminate food take a long time to adjust to the surrounding environment and called adjustment phases or lag phases. The lag phase is highly depended on temperature, so the duration of the lag phase can vary from several hours to several weeks. 
Table 4. Bacterial colonies of milkfish cooked by a high-pressure cooker during storage at room temperature (transformed in the form of logarithm)

\begin{tabular}{cccc}
\hline \multirow{2}{*}{ Drying Time (hour) } & \multicolumn{3}{c}{ Storage Period (day) } \\
\cline { 2 - 4 } & $\mathbf{1}$ & $\mathbf{3}$ & $\mathbf{5}$ \\
\hline 0 & $4.42 \pm 2.03_{\underline{a}}$ & $5.32 \pm 0.03$ & $5.45 \pm 0.02$ \\
4 & $3.86 \pm 0.40_{\underline{b}}$ & $5.03 \pm 0.25$ & $5.34 \pm 0.04$ \\
\hline
\end{tabular}

Values expressed are mean \pm standard deviation

Values with different subscript letters with the addition of underscores in the same column are very significant differences $(P<0.01)$

The number of bacterial colonies for both products increased rapidly at day 3 storage. This may be due to the bacteria had reached the logarithmic growth phase. Bacterial growth occurred very quickly by utilizing the nutrients found in presto milkfish. In addition to utilizing the nutrients of the product, it was suspected that the bacteria also utilized the water contained in the product, because at day 3 the moisture content and water activity of both products was high allowing bacteria to grow and develop. Presto milkfish both dried for 0 hours or 4 hours stored at room temperature so that the temperature and humidity could not be controlled. Those conditions as one of the factors that help to accelerate bacterial growth. Hadiwiyoto (1993), explained that once the bacterial cells adapt to their growing environment, then the bacterial cells multiply. The number of cells is getting more and more. This phase is called the logarithmic growth phase because the number of cells increases logarithmically.

The number of bacterial colonies of both products at day 3 and 5 were not significantly different although tended to increase. This was possibly caused by the bacteria which had entered the stationary phase. In this phase there is no absolute growth, because the number of new bacteria and the number of dead bacteria is the same numbers. Syarief and Halid (1993), explained that in the stationary phase the number of microbes that grow in balance with the dead, as a result of decreasing the amount of nutrients contained in the substrate.

\section{Sensory Evaluation}

The variation of drying time ( 0 hours and 4 hours) did not gave significant difference $(P>0.05)$ to sensory product quality value at day 1 but gave very significant difference $(P<0.01)$ at day 3 and day 5 . The results sensory of milkfish cooked by a high-pressure cooker shown in Table 5.

In the 3rd day of sample for 0 hours, the value of sensory quality began to decrease (4.6) lower than the minimum value according to SNI that is 7.0 while the drying product for 4 hours the sensory value was 7.3 so still fulfilling the required value of SNI. The drying product for 4 hours began to decline after 3 days of storage and at 5th day of storage reached a value of 4.9. These low value products (4.6 and 4.9) were caused by the surface of the product had been overgrown with white fungus, which made the acidity began rose and in result the taste became less tasty and slightly acid. Additionally, the texture also became less solid, less compact, and soft. 
Table 5. Sensory value of milkfish cooked by a high-pressure cooker during storage at room temperature

\begin{tabular}{cccc}
\hline \multirow{2}{*}{ Drying Time (hour) } & \multicolumn{3}{c}{ Storage Period (day) } \\
\cline { 2 - 4 } & $\mathbf{1}$ & $\mathbf{3}$ & $\mathbf{5}$ \\
\hline 0 & $7.3 \pm 0.14$ & $4.6 \pm 0.49 \underline{\mathrm{b}}$ & $1.4 \pm 0.52 \underline{\mathrm{d}}$ \\
4 & $7.4 \pm 0.16$ & $7.3 \pm 0.20 \underline{\mathrm{c}}$ & $4.9 \pm 0.57 \underline{\mathrm{e}}$ \\
\hline
\end{tabular}

Values expressed are mean \pm standard deviation

Values with different subscript letters with the addition of underscores in the same column are very significant differences $(P<0.01)$

The appearance of mold on the surface of the product was presumably due to the product being stored at room temperature and not packed with vacuum so that the moisture content of the product could rise in accordance with its environmental condition as well as the product could be contaminated with mold spores through air contact. Consequently, raising the moisture content of the product would accelerate the growth of mold on the surface of the product. Supardi and Sukamto (1999), explained that foodstuffs when stored in moist areas, the moisture content of these foods will rise because they absorb moisture from the environment that will trigger the growth of fungi. Fungi belongs to the mesophilic microorganisms that grow optimally in the temperature range between $25^{\circ} \mathrm{C}-30^{\circ} \mathrm{C}$ and aerobically live (Winarno, 1994). The deterioration of quality also characterized by the emergence of acid odors that are suspected due to the decomposition process of chemical composition, especially protein by microorganism activity. This is in accordance with the statement Hadiwoyoto (1993), that the activity of protein was broken down by protease enzymes produced by bacterial decay that will cause bad smell. Murniyati et al. (1993), explained that the occurrence of unpleasant odors is caused by bacterial activity to produce proteolytic enzymes that will break down proteins into simpler compounds such as amino acids and $\mathrm{NH}_{3}$ which will eventually produce compounds such as $\mathrm{H}_{2} \mathrm{~S}$.
Decreased product quality is characterized by a bland and slightly acidic taste suspected as a result of the breakdown of proteins and fats by bacteria and produce the formation of simpler compounds that cause the taste of the product to be acidic. Heruwati et al. (1985), explained that the transformation of proteins and fats will result in the formation of alkaline compounds and cause off flavor.

The change in texture of the product becomes less dense, less compact and flabby because the constituent components of the texture in fish meat damaged by the activity of microorganisms that could not support the structure of fish meat. Hadiwiyoto (1993), explained that the damage to the components of fish meat, especially protein muscle tissue will lead to the release of water bonds so that fish meat loses its ability to hold water. While the formation of suspected mucus due to the breakdown of protein by the activity of microorganisms on products that cause the formation of mucus that smells unpleasant. In the opinion of Buckle et al. (1987), that the formation of mucus is caused by the hydrolysis of starch substances and proteins that will produce adhesive substances. Rab (1997), explained that microorganisms also produce sugars that will cause mucus on the surface of foodstuffs.

\section{Conclusion}

Milkfish cooked by a high-pressure cooker dried for 4 hours produces better product than dried for 0 hours product because based on sensory value, moisture 
content, bacterial colonies and water activity still fulfill SNI requirement with 3 days storage at room temperature.

\section{References}

Anonim. 2015. SNI 2332.3:2015, Cara uji mikrobiologi - Bagian 3: Penentuan Angka Lempeng Total (ALT) pada produk perikanan. National Standardization Council.

Anonim. 2015. SNI 2354.2:2015, Cara uji kimia - Bagian 2: Pengujian kadar air pada produk perikanan. National Standardization Council.

Anonim. 2009. SNI 4106.1:2009, Bandeng presto- Bagian 1: Spesifikasi. National Standardization Council.

Adnan, M. 1982. Aktivitas Air dan Kerusakan Bahan Pangan. Penerbit Agritech. Yogyakarta.

Alyani, F., Ma'ruf, W.F. and Anggo, A.D. 2016. Pengaruh lama perebusan ikan bandeng (chanos chanos forsk) pindang goreng terhadap kandungan lisin dan protein terlarut. Jurnal Pengolahan Dan Bioteknologi Hasil Perikanan. 5(1): 8893.

Astawan, M. 2003. Bandeng Presto: Makanan Masa Mendatang. http: //www.kompas.com/kesehatan/news/0 305/01/104518.htm. Accessible date 23 May 2006.

Buckle, K.A., R.A. Edwards, G.H, M. Wootton. 1987. Ilmu Pangan. Penerbit Universitas Indonesia. Jakarta. (translated by Hari Purnomo and Adiono).

Djarijah, A. S. 1995. Ikan Duri Lunak. Kanisius. Yogyakarta.

Hadiwiyoto, S. 1993. Teknologi Pengolahan Hasil Perikanan Jilid I. Penerbit Liberty. Yogyakarta.

Heruwati, E. S., Kamarijani dan Soedarsono, J. 1985. Pindang bandeng kudus: pengamatan selama pengolahan.
Laporan Penelitian Teknologi Perikanan. 41, 7-14.

Hornby, A. S. 2000. Oxford Advanced Learner's Dictionary. Oxford University Press. New York.

Ibrahim, R. 2003. Peningkatan kualitas bahan baku, sanitasi dan hygiene pada proses pemindangan ikan. Jurnal Ilmiah Universitas Semarang. 10 (8), 200-213.

Kanoni, S. 1991. Kimia dan Teknologi Pengolahan Ikan. Pusat Antar Universitas Pangan dan Gizi Universitas Gadjah Mada. Yogyakarta.

Moedjiharto, T. J. 2002. Peningkatan Mutu Gizi Protein Pindang Ikan Layang (Decapterus macrosoma Blkr.) dengan Optimasi Proses Pemindangan. http://www.digilib.brawijaya.ac.id/virtu al_library/mlg_warintek/disk8.htm. Accessible date 14 May 2006.

Murniayati, Setiabudi, E. and Rahayu, S. 1993. Pengaruh perebusan terhadap mutu teripang pasir (Holothuria scraba) dan teripang batu (Holothuria nobilik) rebus pada penyimpanan suhu kamar. Jurnal Penelitian Pasca Panen Perikanan. 75: 11-24.

Pandit, IGS. 2004. Teknologi Penanganan dan Pengolahan Ikan. Penerbit. PT. Bali Post. Denpasar.

Rab, T. 1997. Teknologi Hasil Perairan. Penerbit Universitas Islam Riau Press. Pekanbaru. Saparinto, S., Purnomowati, I. dan Hidayati, D. 2006. Bandeng Duri Lunak. Penerbit Kanisius. Yogyakarta.

Sarnianto, P., Putro, S., Poernomo, A., Retnowati, N. and Rahayu, U. 1984. Pengaruh garam dan larutan garam kadar rendah terhadap perubahan aktivitas air (Aw) dan daya awet pindang. Laporan Penelitian Teknologi Perikanan. 31, 1-8.

Skipnes, D., Ostby, M.L. and Hendrickx, M.E.2007. A method for characterising 
cook loss and water holding capacity in heat treated cod (Gadus morhua) muscle. Journal of Food Engineering 80: 1078-1085.

Sudarisman, T. and Elvina A.R. 1996. Petunjuk Memilih Produk Ikan dan Daging. Penerbit Swadaya. Jakarta.

Supardi, I dan Sukamto. 1999. Mikrobiologi dalam Pengolahan dan Keamanan Pangan. Penerbit Alumni. Bandung.

Syarief, R. and Halid, H. 1993. Teknologi Penyimpanan Pangan. Penerbit Arcan. Jakarta.

Winarno, F.G. 1984. Kimia Pangan dan Gizi. PT Gramedia Pustaka Utama. Jakarta.

Winarno, F.G. 1993. Pangan : Gizi, Teknologi dan Konsumen. PT Gramedia Pustaka Utama. Jakarta.

Wojowasito, S. 1982. Kamus Umum Lengkap Inggris-Indonesia. Penerbit Pengarang. Bandung.

Yusnainia, Soeparno, Suryanto, E. and Armunanto, R. 2015. The effect of heating process using electric and gas ovens on chemical and physical properties of cooked smoked-meat. Procedia Food Science. 3: 19-26. 